\title{
Review on Indonesian zakah management and obstacles
}

\author{
Mutiara Dwi Sari", Zakaria Bahari, Zahri Hamat \\ Centre for Islamic Development Management Studies, School of Social Sciences, Universiti Sains Malaysia, 11800 Penang, Malaysia
}

Email address:

mutiara_dwisari@yahoo.com(M. D. Sari)

\section{To cite this article:}

Mutiara Dwi Sari, Zakaria Bahari, Zahri Hamat. Review on Indonesian Zakah Management and Obstacles. Social Sciences. Vol. 2, No. 2 , 2013, pp. 76-89. doi: 10.11648/j.ss.20130202.18

\begin{abstract}
This paper presents a conceptual model a management of zakah in Indonesia. A variety of reforms and new ideas in the management and institutions are responsible for collecting and distributing of zakah. Zakah is a specific property with certain conditions prescribed for certain people and given to people or certain people (recipients) as well. The main aim of zakah has two dimensions i.e., spirituality (individually) and social economy to empowerment and enhance the status of the ummah (community). Indonesia as a country with huge Muslim population has great potential in the collection and distribution of zakah. If zakah is managed properly, it will certainly have positive effect on the well-being of poor Indonesians. In 1999 the government of Indonesia issued the Law on the management of zakah, from the moment zakah management in Indonesia entering a new era. Zakah management becomes more professional and systematic. There are two of zakah collections and distribution, i.e. governmental approach and nongovernmental approach. Government established approach consists Badan Amil Zakah (BAZ) and Baitul Mal, meanwhile nongovernmental approach consists Lembaga Amil Zakah (LAZ) (such as Dhuafa Wallet and Zakah Home), Mosques, Islamic Boarding School (pesantren) and Individually. Lack of coordination between all institutions of zakah management has resulted in the achievement of zakah collection and distribution does not optimum. The existence of the trust to the board of the crisis the government formed between the inhibited zakah management of Indonesia. Besides the sociological aspects of weakness, juridical aspect is also one reason why potential zakah Indonesia has not fully handled.
\end{abstract}

Keywords: Zakah Management, Governmental Approach, Non-Governmental Approach, Indonesia

\section{Introduction}

Zakah is payment required by Islam to its followers who have property in various forms, if sufficient conditions (haul) or period and nisab or a minimum amount sufficient to meet basic needs for a period of imposed [1].Reference [2] said that according to Islamic law, zakah is a certain property is issued with certain conditions to people or certain people (recipients). References [3] and [4] divided meaning of zakah into three terms i.e. linguistically and literal, theologically and legally. By linguistically, zakah means cleansing or purification of something from dirt or filth. Zakah also is "growth" and "increase". Growth can be seen from various perspectives. This includes both psychological growth and material. Not only that, on the recipients' side there will be growth or increase in their wealth too. In other words, whoever rightly performs zakah obligation would be given an increase in his or her wealth. Simply put, any asset or amount paid as zakah is promised to grow significantly, in many different aspects including spiritual, psychological and financial - benefiting payers as well as the entire economy [5]. Increase can also be interpreted in many ways including increasing the payer's good deeds resulting in an increase in their religious merits and blessings [6]. By theologically, it means spiritual purification resulting from giving of zakah. As well as Allah says in As-Syams verse 9 He has succeeded who purifies it. Reference [7] also explained that the meaning of zakah is growing and a blessing of the holy. While according to [8] zakah means holy and grow. By legally, zakah means transfer of ownership of specific property to specific individuals under specific conditions. Muslims have the obligation to give a specific amount of their wealth (with certain conditions and requirements) to the specified beneficiaries

Zakah is one of the Islam pillars which the second is Shalat and Zakah is belonging to the third pillar. Zakah is regulated by the Allah or Divine Laws termed in Al-Qur'an as Tawhid and Prophetic Guidance or Sunnah Rasul. "Keep up prayer and pay Zakah", is the constant theme of the 
Holy Qur'an. Based on the above definition it can be concluded that, the meaning of zakah is the number of properties given to certain people as a duty of the Syariah (Islamic Laws) who have certain properties in accordance with provisions applicable to certain conditions. On the other hand, zakah is also a sign of Muslim thanks to Allah for sustenance and wealth which Allah has given to him. For the believer he/she is optimistic that his/her properties are owned by other people as well. There are at least 27 passages in the Qur'an where the order to pay zakah and the order to establish prayer occur jointly. From this statement we can see the significant of zakah in Islam.

Payment obligation of zakah as the third pillar of Islam began at the time of the Prophet sent ibn Jabal to Yemen. As reported by Imam Bukhori (No.478), Ask them to say that there is no God but Allah, and that I am the messenger of Allah, if they obey you shall tell them that God requires for them to prayer five times a day and night, if they obey him should you tell them that God requires them to perform zakah on their property. Property was taken from the rich and given to the poor among them.

Indeed Islam recognizes private ownership; however it is not absolute and unconditional. Authors [9] said any property is not totally owned by the person and the real owner is Allah and that wealth given by Allah is in trust [10] as a Trust (Amanah) [11]. Allah says in Al-Ma'rij verse 24, And those within whose wealth is a known right. Allah also says in Al-Ma'rij verse 25: For the petitioner and the deprived. Indeed Islam recognizes private ownership; however it is not absolute and unconditional. Islam would not deny self-interest but would put self-interest in perspective with social ethical responsibility [12].

Zakah has constituted one of the most important products of Islamic civilization; there are other fundamental objectives that we do not believe are possible to realize except by institutionalized efforts that cover all sectors of the society [13]. In this paper will explain the Indonesian zakah management and the obstacles from the way to collect and to distribute. The remaining of the paper is structured as follows. The next section will discuss the objectives of zakah. Section 3 of this paper discusses the management and institutions of zakah in Indonesia. Section 4 Looks into the obstacles of management and institutions of zakah and its implications. Section 5 is conclusion.

\section{Objectives of Zakah}

Discussion about zakah not only religious problem but it has other dimensions of worship. Zakah is a financial and economic mechanisms of worship, and between the goal is to purify the human soul and its properties because it is probable that the rights of others in the process of acquiring the property [14]. Allah says in Adz-Dzaariyat verse 19 and from their properties was [given] the right of the [needy] petitioner and the deprived. Zakah can show how a Muslim put him or herself in the community. This sense of collective responsibility is further reinforced by how the Muslim views his/her place within society. Islam, it should be emphasized, is not concerned with the welfare of the individual alone; it seeks to achieve a wider societal well-being. While ensuring the individual's freedom, it places equal stress on mutual responsibility [15]. Islam would not deny self-interest but would put self-interest in perspective with social ethical responsibility and with behavior in the context of rules and norms, which are governed by Syariah [10].

The individual achieves balance between thought and action (internal), while caring for the collective welfare of society (external) $[16,17]$. The objective of zakah as general has two different dimensions Spirituality (individually) ubudiyah (divinity) and Social Economy (iqtishadiyyahi $[18,19]$. By spirituality (individually), zakah is closely related to worship [20]. This is because most real purpose of zakah is to worship and devotion only for Allah [21]. Allah says in Al-Baqarah verse 110 And establishes prayer and give zakah, and whatever good you put forward for yourselves - you will find it with Allah. Indeed, Allah of what you do, is seeing. Reference [22] notes that some Muslim scholars claim that the Qur'an mentions zakah in 82 places, while according to Qardhawi himself, the word is stated some 30 times, while 27 occurrences are affirmed together with the order of Shalat or regular prayers. From this statement one should be informed of the importance of zakah in Islam, which is like a synergy to prayer. For this reason, reference [18] states, if prayer is the pillar of religion, the religion of zakah is the lighthouse. First dimension was more referring to the individual business within the meaning of a direct relationship with God to obtain peace of mind. Allah says in Al-Tawbah verse 9 Take, $[\mathrm{O}$, Muhammad], from their wealth a zakah by which you purify them and cause them increase, and invoke [Allah's blessings] upon them. Indeed, your invocations are reassurance for them. And Allah is Hearing and Knowing.

In the social economy aspect, reference [9] stated zakah is the cornerstone of the financial structure in Islamic to achieve of socio-economic justice [23]. Therefore, zakah, other than for purposes of worship also have economic purposes. The purposes of zakah for socio economic aspect are;

1) Distribution of income [24]. According to [25] zakah causes augmentation in consumption through the amelioration of the very poor and deprived.

2) Eradicate poverty [5, 26, 27]. Zakah is a unique instrument for poverty alleviation as wealth is transferred from well-off people to worse-off people $[28,29]$ to maintain economic justice [30], to protect the socio-economic welfare of the poor and the needy [31] and for community social welfare and created equilibrium between social classes in an equitable [13, 19, 32]. All these economic and social purposes will refer to a goal of community empo- 
werment and to enhance the status [6,33]. Quite different from the purpose of zakah in the first dimension, in this social economy dimensional, the purpose of zakah also involves a relationship or dealings with the community and the environment. That is why the zakah is said to be unique from other worship, because it does not depend on the individual but also involves many parties.

Zakah not only impact on zakah obligator or muzakki, but will also impact on the social community. Because the zakah has a dimension socioeconomic, there needs a good management system in the collection and distribution of zakah can run optimally and provide more efficient and effective result.

\section{Management and Zakah Institutions in Indonesia}

The basic management of zakah is based on the decree of Allah in Surah At-Tawbah verse 60: Zakah expenditures are only for the poor, the needy and for those employed to collect zakah. Other important reasons for zakah are for bringing hearts together [for Islam], for freeing captives [or slaves], for those in debt, for the cause of Allah and for the [stranded] traveler - an obligation [imposed] by Allah, and Allah is Knowing and Wise. In some countries with huge Muslim population such as Indonesia, the effort to manage zakah has showed a remarkable and promising. It has rather broadened to institutional payers like companies or corporations [5]. As simple the meaning of zakah is the issue of property in a certain amount for certain people. In doing so, there are certain rules that involve many parties. Zakah and Hajj are in contrast to three other pillars of Islam, the Shahada, prayer and fasting. These three pillars lead to personal needs or in other words it is "Pillars of Privacy", which depends on personal matter. Meanwhile, zakah and pilgrim are more on community management which is referred to as "Pillars of Society". Therefore, the management of zakah (and pilgrims) is more complex [34]. This means the muzakki must believe in the body in charge of zakah management. Meanwhile, zakah collection and distribution managements should exhibit professionalism and trust in maintaining the interest of zakah recipients (mustahiq). This represents the circle of trust which will be able to bring maximum benefit. It signifies a circle of trust for maximum benefit. This section will discuss the management of zakah and zakah institutions that exist in Indonesia.

\subsection{Management of Zakah}

Zakah management is the most critical aspect in determining the direction of the zakah. Management and distribution system of organized collection, and adequate manpower would ensure optimization of the zakah [35]. There are various methods of zakah management in countries with a majority of the population is Muslim. The govern- ments of the Muslim countries have a number of different approaches implementing zakah [30]. For example, in Yemen, zakah management made directly by government or under specific ministries [36]. This situation is also similar to Sudan [37], Pakistan [38], Singapore [39], Brunei Darussalam [40], Malaysia [41] and Saudi Arabia [42].Meanwhile, at Kuwait and Egypt, zakah management made by semi government institution [43, 44].In other countries such as Jordan, Iraq, Tunisia and Bangladesh, the management of zakah done by independent institutions [44]. In Bahrain and Oman, the countries have enacted laws of zakah and established zakah organizations supported by their government but they left zakah payment to these organizations to remain on voluntary basis. Ideally, the management of this zakah was done by the government [45]. Government responsible for carrying out the collection and distribution and to make some regulations to ensure the zakah is done by good management. This issue has been exemplified by the Prophet during his reign, whereupon the Prophet had appointed staff zakah for every area that has been converted to Islam [18]. Their job is to assess, collect, determine the size requirements mustahiq, distribute and became cashier of zakah fund [38]. This situation held until the time of al-Guided Caliphs.

How is the situation in Indonesia? Until 1968, zakah in Indonesia operated from the bottom (the community) without government interference. There is no official body formed a government (except in Aceh who had arranged the zakah management since 1959) [46]. The management of zakah by community-based systems has been in existence even before the Republic of Indonesia was formed. People deliver their zakah directly to mustahiq, religious leaders, mosques and pesantren (Islamic traditional boarding school) [47]. This happen, until the government issued the Law (UU) No.38 years 1999 on the Management of Zakah. What Institutions which manage the zakah in Indonesia after the issuance of Law? This will be discussed in the next section.

\subsection{Zakah Institutions in Indonesia}

Indonesia has seen many reforms of the zakah and wakaf (religious endowment) institutions [48]. Institutions and management of zakah in Indonesia is quite interesting to study because Indonesia is a country with the largest Muslim population in the world and able to provide bigger potential of zakah. The population of Indonesia reached 237 million [49]. Approximately $86 \%$ of the total population of Indonesia is Muslim. This means the total Muslim population in Indonesia is about 204 million. Based on the survey from the Public Interest Research and Advocacy Center [50], about 55\% of Indonesian Muslims (around 112 million) categorized as zakah obligatory or muzakki.

Referring to the history of zakah management in Indonesia, most Muslim communities perform zakah individually 
and/or by other traditional methods. Government involvement began in 1968 with the Joint Decision Letter issued by the Minister of Religion and the Minister of Home Affairs that governed the conduct of zakah. This was followed by the establishment of the zakah and syadaqah collection body called Badan Amil Zakah and Syadaqah (BAZIS) in various provinces. At the same time people also began to establish their zakah management bodies through various religious organizations. Dhuafa Wallet is example of zakah management organized by journalist. Zakah and wakaf are playing a greater role in the socioeconomic uplifting of people. In the case of Indonesia, this is even more important due to the widespread problem of poverty and the relative inadequateness of government policy since the 1960 s to combat the problem [48]. In general, the management of zakah (collection and distribution) in Indonesia is carried out through two approaches. These approaches namely are governmental approach (BAZ and Baitul Mal) and nongovernmental approach. Nongovernmental approach specifically by through NGOs or Lembaga Amil Zakat (LAZ) such as Dhuafa Wallet and Zakah House. Other method for zakah payment is through mosques and pesantrens and directly by muzakki (individually). Details of each of this method are discussed below.

\subsubsection{Governmental Approach}

Under the governmental approach, there are two institutions involve namely Badan Amil Zakah (BAZ) and Baitul Mal. Detail discussion on both institutions will provide below.

\section{A. Badan Amil Zakah (BAZ)}

BAZ is the operational of Law (UU) No. 38 years 1999 on zakah management, followed by the release of the President Regulation No. 8 years 2001 regarding the national body for organizing zakah. In these regulations, zakah at national level was to be managed by a special body called the Badan Amil Zakah (BAZ). At national level known as BAZNAS and at the Province/District level called BAZDA Exception was awarded for Aceh province, which was allowed to establish its own BAZDA-like known as the Baitul Mal. Indonesian government has also issued the Zakah Management Technical Guidelines through decision of the General Director of the Islamic Community and Business Coaching Hajj No.D/291 year 2000. In this decision, detail guidance on the management of zakah is provided. BAZNAS authority is under the Ministry of Religion and led by a chief appointed by the Minister of Religion. Meanwhile, BAZDA authority is under the district government leader and led by a chief appointed by the Governor (province level) or by the Regent (district level).

These bodies were established with the vision of becoming a national zakah trustee bodies with transparency and professionalism in the general management of zakah. The main purpose of these bodies was to increase awareness of zakah among Muslims in Indonesia. In addition they were to build and to enhance the well-being of humankind, both physically and spiritually through zakah empowerment. These bodies were also intended to help the mustahiq to perform as muzakki. Developing the culture of given rather than receiver was also the target of these bodies. BAZNAS currently working with 66 networks have a zakah serving unit (UPZ) spread around the world. For the district, BAZNAS has 33 partners BAZDA. To ensure transparency to the public, the official website BAZNAS have to show all the activities and financial reports regularly. Each year, this body will also perform audit by a professional auditor and financial reporting appears on the official website as a guarantee of transparency BAZNAS. Amount of zakah collection only by BAZNAS, is reach around Rp8 billion per year. The amount collected by all partners working BAZNAS and network (UPZ, BAZDA and LAZ) in 2007 was around Rp. 361 billion [51]. This amount is believed to increase every year. The funds used to finance all BAZNAS program such as smart Indonesia, prosperous Indonesia, Indonesia cares, Indonesia piety, Indonesia healthy and UPZ network expansion.

Smart Indonesia program is a program of scholarships to undergraduate students who come from poor families. Scholarships also provided to poor students studying in Primary and Secondary Schools or the DINNAR fund. Other programs are mobile and smart motor that provides bookmobile to rural and remote areas. Indonesia program of cattle is a community empowerment program through farm fields. Each year, Indonesia imported 450 thousand cattle from Australia due to low production of meat that is not enough to meet the market demand. Therefore BAZNAS see this opportunity as an effort to improve the economy, which focuses on recipients of the people most of the small farm. The last program is entrepreneurial training program aimed at providing skills to dhuafa, until they are able to do activities and run businesses.

\section{B. Baitul Mal}

There is difference between the bodies of zakah in Nangroe Aceh Darussalam Province (NAD) and other provinces of Indonesia. NAD province has the authority in implementing Islamic Syariah as stated in Regulation No. 14 of 1999 and Regulation No. 18 of 2001. This authorization is set out again in the Regulation No. 11 of 2006. Zakah has found a place specifically through the establishment of the rule of Baitul Mal, based on Qanun of Aceh (Regional Regulation) No. 10 of 2007 [52]. The main task of Baitul Mal is to collect and distribute zakah among the people of Aceh. At the provincial level, the management of Baitul Mal is appointed and dismissed by the Governor, while at the District level, the appointment and dismissal is made by the Regent.

Reference [53] stated that there are three fundamental differences between Baitul Mal and BAZDA namely: 1) Zakah collected by Baitul Mal is regarded as a source of 
Natural District Revenue (PAD) of the Province/District, while zakah collected by BAZDA is not part of PAD 2) Baitul Mal is allowed to collect zakah using a reducing factor of the amount of income tax owing or tax credits. Meanwhile, BAZDA is only allowed to reduce the "total taxable income" or tax reduction as far as zakah collection is concern and 3). The operational costs of the Baitul Mal are taken from the Local Development Budget (APBD), while the operational costs of BAZDA is prepared by the BAZDA itself. For government officials, the amount of zakah is to be paid directly by being deducted at the office of Treasurer from the payment of monthly salaries and submitted to the Baitul Mal. For civilians, they can simply pay zakah to Baitul Mal.

Programs conducted by the Baitul Mal are Zakah Productive Management Unit (UPZP), fakir excuses care Unit (UPFU), scholarship programs for the recipients 'ibn sabeel', program of infrastructure development in areas prone to the worship or faith in Fissabilillah, assistance to poor families in every Eid ul-Fitr, scholarship programs for children in districts with dangerous convert activities and disaster/fire relief programs [53]. All resulting collection of zakah is considered as income of Natural District (PAD). As a consequence zakah for all government stooges NAD directly cut by the general treasurer district. So the funds raised at the Baitul Mal must first be kept in the treasurer of the government before distribution to the recipients. The total zakah collected in NAD in 2009 was Rp. $3,419,814,770$. This amount does not include zakah from the government stooge who cut the General Treasurer of the District with a total of Rp. 3,010,363,869 [54].

Among the main program of NAD Baitul Mal is Zakah Productive Management Unit (UPZP), Fakir Excuses Care Unit (UPFU) scholarship program through the recipients 'ibn sabeel'; program of infrastructure development in areas prone to worship the faith of the recipients Fisabilillah; assistance program for poor families on every Eid ulFitr; scholarship program for children in the area of cartilage converts faith; disaster relief programs / fire to the needs of the time to panic. Baitul Mal Productive zakah programs have been implemented that include the provision of muddy (three-wheeled car), the provision of micro venture capital (micro finance) for vegetable farmers and traders in traditional markets and the expansion of beef cattle pilot projects [54].

\subsubsection{Non Governmental Approach or}

Under the nongovernmental approach, there are four institutions involve namely Lembaga Amil Zakah (LAZ) (such as Dhuafa Wallet and Zakah Home), Mosques, Islamic Boarding School (pesantren) and individually. Detail discussion on all institutions will provide below.

\subsubsection{Lembaga Amil Zakah (LAZ)}

Under the LAZ approach, there are several institutions involved. In this article will discuss the earliest LAZ insti- tutions and popular in Indonesia there are Dhuafa Dompet (DD) and Zakah House (RZ).

\section{A. Dhuafa Wallet or Dompet Dhuafa (DD)}

DD initially began of journalists in Republika newspaper that active collecting 2.5 percent of their income for zakah. This movement started in the collective empathy journalist community that many interacting directly with the poor, thus often met with the rich. At the moment this zakah management is simple and traditional. Funds rose directly channeled to the dhuafa that they frequently encounter while working in the field.

In 1993 they established a foundation to collect zakah from the community, especially through the Republika newspaper journalists and readers, and to distribute collected zakah to eligible recipients. The foundation is named as Dhuafa Dompet (wallet) Foundation (also known as Dompet Dhuafa or DD). DD continue to progress each year. DD receives support from the community and has become the first Indonesia LAZ. DD is working to help dhuafa with the ZISWAF funds (Zakah, Infaq (donation), Syadaqah (Voluntary) and Waqaf (Endowments), as well as other funds lawful and legally collected from private groups, companies or organizations registered in Indonesia. The steps adapted and followed by DD have driven the growth of LAZ in Indonesia which is known to manage zakah in trust and professionalism.

Programs conducted by DD include education, health, social, economic, disaster relief, and business development. In education, the DD is providing scholarships, establishing boarding schools, building the capacity of teachers and many more activities. In health, DD provides free medical treatment for dhuafa poor people. Social assistance provided is in the form of food and cloth assistance. Assistance is also provided for skills development of dhuafa poor people until they are self-reliant. In the economic field, DD has set up microfinance activities such as Baitul Mal wa Tamwil/BMT center and Baitul Mal village. The program is committed to the empowerment of farmers, ranchers, communities, and special communities such as pitchman. For farmers and ranchers DD provide them with trainings and conduct or support researches aim to help them increase their production and to better their livelihoods. DD currently has 15 branches, including in Hong Kong and Australia with representative offices of 9 plus 8 networking. The average number of zakah collected by DD around Rp. 15-20 billion per year, not including funds infaq, Voluntary and contributions from donors. The entire amount raised is channeled to finance all the programs and assistance mentioned above. DD according to [48] have both mobilized zakah and waqaf as institutions playing a greater role in the socioeconomic uplifting of people. In the case of Indonesia, this is even more important due to the widespread problem of poverty and the relative inadequateness of government policy since the 1960 s to combat the problem. 


\section{B. Zakah Home or Rumah Zakah (RZ)}

Similar to the DD, Zakah Home or Rumah Zakah (RZ) is a LAZ established at May 1998 in Bandung, West Java. This organization was originally called Ummul Quro Social Wallet (DSUQ) and was pioneered by Ustadz Abu Syauqi whose focused was more on professional management of zakah, donation, and endowment shadaqah. This organization has been strengthening its existence at the national level as LAZ, based on Decree Minister of Religion No. 157 of 2003. RZ was established with the mission to develop self-reliance and community service. RZ enforces three new values, they are; Trust, Progressive, and Humanitarilism, as well as introducing a new position of confidence sharing. Sharing confidence means that RZ has a strong confidence in sharing and creating a better global civil society. Therefore, RZ as well as DD is an example of LAZ in Indonesia which has pioneered the effort to empower zakah.

RZ uses modern management and it is led by a CEO. RZ emphasize on programs in education, health, community building and economic empowerment of the community. There are four main programs (referred to as 4Cares), thus HealthCare, EduCare, EcoCare, and YouthCare. To maximize community empowerment, 4Cares service units have been established in 8 Schools, 7 Free Maternity Homes, 20 Free Maternity Cares, 18 Cooperative Syariah Mosaic, and a Youth Development Centre (YDC). RZ is implemented in an integrated program in an area called the Integrated Community Development (ICD). ICD is the networking of $\mathrm{RZ}$ that has spread throughout Indonesia.

In RZ, each ICD is managed by a Mustahiq Relation Officer (MCO). To ensure that the work program is monitored, MCO should be at the heart of the community being served. Cost for all activities originating from zakah, donations, Syadaqah and endowments. Total contributors to RZ is around 87.300 people and it supports about 634 people including those who carry out office and non-office functions, funding, and other personnel programs. EcoCare is done through small and micro-financing and has been able to help 26,803 people with a revolving fund of Rp. 29 billion. Youth Care also recorded 14,291 joined volunteers and 5,495 volunteers from all parts of Indonesia are considered to be very active. Youth Care programs include community development activities, emergency rescue teams, and community assistance. The HealthCare program has an ambulance unit, funeral transportation unit and mobile clinic unit. Maternity Homes have provided free health screening, antenatal and other medical services. EduCare helps foster children through scholarship programs referred to as Returning the Smile of Indonesian Children or Kembalikan Senyum Anak Bangsa (KSAB). The potentials of children are also increased through the Center for Child Potential (P3A) which is available in 13 Cities. Kids Learning Centres and a place where children are mentored are also available.

\subsubsection{Mosques}

The mosque is a ritual institution. According to historical records the mosque was first Islamic institution established [55]. Mosque as a building used for congregational prayers, Friday prayers, meditate and certain rituals and have a certain prestige value. The wider meaning given by [56], the mosque was the center of community life, the center of worship and business transaction. Mosques are also made one of the Muslim faith benchmarks. Allah says in AtTawbah verse 18 The mosques of Allah are only to be maintained by those who believe in Allah and the Last Day and establish prayer and give zakah and do not fear except Allah , for it is expected that those will be of the [rightly] guided.. Flourishing mosque is steadfast in prayer in it praying, chanting and upholds the offerings consecrated to Him. At the time of the Prophet and the Rightly Guided Caliphs al-, the mosque has performed its role as the heart and pulse of the community. Mosque is the cause of Muslim life, both spiritually and materially. Material referred to here as stated by [57] at the time of Allah's Messenger's mosque functions are not limited to specific acts of worship such as prayer and exercise alone. Mosque is also responsible for performing other developments such as working as a citadel of Islamic teaching, central government and administration, science centers, financing and banking center, a place to claim rights and justice, military bases and defense and welfare center. Therefore Mosques, besides serving as a center for religious activities, also serve as a center for economic and social activities

In term of zakah, one of the characteristic Islamic Symbols on zakah management can be seen in the mosque. Reference [56] states that the mosque is the most appropriate place to pay and receive zakah. In the mosque, Baitul mal place, where funding for community welfare issue. Zakah is collected and distributed, zakah, booties and other divided. Mosque could act as a 'mosque institution'; the mosque should have a role as a center for the payment of zakah (PPZ), where the role of the mosque to collect zakah fitrah can be extended not only for zakah fitrah, but also for zakah property. Thus people some time need not go to the Islamic Religious Department in the city to pay zakah property, but enough to pay zakah property at the mosque.

Zakah Management at the mosque is not a new things, it already practices at the time of the Prophet. This practice has been committed in the city of Medina, especially in large mosques (jami'a) as the place where Muslims gather [58]. Therefore, based on historical factors and the practice by the Prophet, the mosque is a place of management due to many elected public zakah. However, for the orderly and efficient management and monitoring facilities is required one center (central) which connects all small mosques involved in the collection of zakah. So if there is zakah collection centers either in the village, district or state, it must be connected to the main mosque of the jami'a. This method is known as zakah localization $[59,60]$. 
In Indonesia, for centuries mosques and pesantrens were organizing zakah and they are the first institutions to organize zakah, even if it was done in the conventional. Mosques and pesantrens have played an important role in organizing zakah, before BAZ and LAZ were established. Data from the Indonesia Ministry of Religion showed that, the number of mosques in Indonesia reached over one million. This data does not include small size mosques called Mushalla and Surau. This number make Indonesia is the country with the highest number of mosques in the world. The larger number of mosques and pesantrens together with their wide networks are tremendous source of strength in organizing zakah. Reference [61] states that mosques can indeed be a center of economic and social activities apart from being a base camp of worship.

In fact in Indonesia, the mosque is an institution that is very trusted by the community. Research by PIRAC show that BAZ and LAZ only selected by $7.2 \%$ muzakki as a channel for the payment of zakah, meanwhile the mosque chosen by $60 \%$ of muzakki [50].As the chief of the mosque in general is a person trusted by the community. The height of this belief is in fact the potential basis for the collection of zakah through mosques. In psychological and sociological views, the mosque was an institution that has the closest relationship with the heart of Muslims when compared to other institutions. This was shown by studies [62] in town of Malang, that the mosque is known by all the institutions muzakki respondents $(100 \%)$. While for BAZ and LAZ, is known and recognized by muzakki with an average of $50 \%$.

Because of management of zakah through many traditional mosques makes it less effective and more difficult. Only few mosques in major cities adopt modern management [51]. It is the right time for the mosques to improve the management of zakah especially in the collection and distribution of zakah. The successful management of zakah by the mosque is a measurement of the prosperity of the mosque itself. Therefore the government of Indonesia through BAZNAS provides training for mosque committees that managed zakah so that the management of zakah can be done better. In the implementation of the management of zakah in the mosque, normally a special committee called the zakah collector unit (UPZ) is formed. Regulation No. 38 year 1999 noted that the UPZ is to spearhead the collection of zakah in the mosque [63]. In the year 2008, the Indonesia Ulama Association (MUI), BAZNAS, Indonesian Mosque Committee, the Task Manager of Istiqlal Mosque, Indonesia Hajj Brotherhood Association, Association of Muslim Scholars of Indonesia (ICMI) and other organizations agreed to make UPZ as one of the institution to spearhead zakah collection.

\subsubsection{Islamic Boarding School (Pesantren)}

Pesantren institutions are also involved in zakah management [64]. Pesantren interpreted literally as a dormitory, where santri, or where the students study the Islam. There are a lot of sense in terms of boarding school, and of all the meaning, yet there is a concrete and comprehensive meaning. An understanding of the pesantren is flexible according to the development time. Pesantren is defined as a traditional educational institution does not happen again. Pesantren has turned into modern educational institutions. Reference [65] defines the pesantren as a place of education and teaching of Islam that emphasizes education and supported hostels for residence santri.

Pesantren considered as "father" of Islamic education in Indonesia [66]. Pesantren It was there for hundreds of years ago that has become a part of life from most of the Muslims of Indonesia [67]. Pesantren is not only available in Java alone, but also in Aceh which called as meunasah or rangkung and in West Sumatra which called as surau. Pesantren cannot be released from the elements of Mosque, huts, Religious Leaders, santri (students) and classic books [68]. Thus, pesantren truly awakened from the construction of community and social epistemology has created transcendence on social historical journey. In center of knowledge, the social climbing, pesantren had undergone a metamorphosis that is rooted in epistemological constructs of understanding variations among Muslims. Things that become important point is the fact of existence of pesantren as a trigger realization of social cohesion. This is because the pesantren present the spirit of simplicity, family and social concerns. Conception of behavior (social behavior) that appears pesantren has high social bounding force and difficult to find on other educational institutions [66]. So gave us the role of the pesantren as being manager of the institution that granted the Muslim charity. Practical management of zakah in pesantren was started during the Dutch colonization era [69]. This activity began on the island of Java, such as in Banten and East Java, where many pesantren were established. At that time pesantren play an important role as a place of learning and the spreading of Islam. People pay their zakah through Kiyai or a religious teacher in the pesantren [70].

The large number of pesantrens, historical factors and their effects on the potential of zakah collection through pesantrens cannot be underestimated. Therefore the management of Zakah through pesantren is still traditional and needs to be improved. Nevertheless the government is not simply ignoring the potential of this pesantren in managing zakah. So, the best way to do, the Government of Indonesia through BAZNAS has partner with pesantren to establish UPZ at each pesantren as well as in the mosques. UPZ in mosques or pesantrens will continue to guide and give training on modern management of zakah to mosques and pesantrens.

\subsubsection{Individually}

Although there are many institutions that manage the zakah, but cannot be denied that the payment of zakah directly to mustahiq stills much to be done [71]. This is caused by three factors. 
First, it is true that Indonesia is a country with the largest Muslim population in the world, but Indonesia is not a country based on Islamic law. In the 1945 Constitution article 29 it is said that the State guarantees the independence of every people. Authors interpret this constitution as provides the flexibility for people that carry out the obligations of religion is "freedom" to them. Including the obligation to pay zakah, and where they will pay. This Constitution secures to them in carrying out their religious obligations and how they do it. According to [70] the grant of freedom is also the underlying principle for Regulation No. 38 in 1999 about Zakah. The law states that the government organizes zakah through its body called Badan Amil Zakah (BAZ) and at the same time allows the community to manage their zakah, through Lembaga Amil Zakah (LAZ).

Second. Conception of zakah is still felt too modest among traditional Muslim Indonesia. Situation has led some people thought enough zakah given directly to poor communities around or to Religious Leaders he wants [72]. The distribution of zakah individually means that the muzakki directly distribute the zakah to the right recipients (asnaf). Distribution is done either by collecting asnaf in the residence of muzakki or the muzakki will deliver it to the asnaf at his/her residence.

Third. BAZ or LAZ distrust to other institutions or even causes a part of people choose to pay zakah directly to mustahiq. Reference [62] found that over 50\% muzakki pay zakah directly to mustahiq. This is due to mistrust of zakah management institutions, especially government formed BAZ.

Many other studies show that muzakki still not satisfied in terms of the distribution of zakah made by the official zakah institutions [14, 58, 60, 73, 74]. Most of these studies found that if institutions do not take note of zakah, it will create a number of other issues such as pay zakah to mustahiq informally or in person and continue direct to mustahiq $[14,60,74,75]$.

However, organizing zakah in this way was done mainly under the traditional method, but it is still allowed by Islamic law (Fiqih). This method of zakah distribution seems to be inappropriate and sometimes can cause unrest and chaos if not done properly. This ever happened in Indonesia, which resulted in casualties when the recipients fought each other in taking zakah. Restless ever happened in Makassar, Lamongan and other places in Indonesia. Unrest that occurred in Pasuruan resulted in 21 casualties when some oppressed poor people were trampled during the uncontrolled distribution of zakah. This situation still reflects the poor management of zakah in Indonesia. A later case was in the distribution of zakah done in Pasuruan regency of East Java to create victims. This case shows that on the other side of poverty is still high, but the sight of yet another management well organized zakah. This is raised up as a result of social imbalance that could lead to potential conflicts in society [76]. Distribution of zakah directly by muzakki to asnaf recipients may be due to lack of confidence in the governing body of Zakah. According to [77] the tendency of people or muzakki to give zakah directly to recipients is as a result of mistrust they have for governing bodies of zakah. It also shows poor management of zakah in Indonesia, particularly by bodies that are established and managed by the government. The reason is associated with lack of socialization efforts to muzakki by the governing body of the zakah. Lack of promotion and information provided to government and stakeholders, resulting in many muzakki not know the existence of these zakah institutions.

\section{Obstacles of Management and Institutions of Zakah}

Many consider after the law No.38 years 1999, the management of zakah in Indonesia showed little progress. This is evidenced by the increasing number of institutions whether BAZ or LAZ created to manage the zakah. As of December 31, 2008, more than 421 zakah institutions have been established. It consists of a 1 National BAZ, 33 BAZ at province level, more than $300 \mathrm{BAZ}$ at districts level, 18 National LAZ and more than $70 \mathrm{LAZ}$ at province or district or city level [78]. However many institutions do not guarantee an optimal management of Zakah. Zakah in Indonesia actually has strategic potential to be developed into an instrument of income distribution. Zakah is one of Islam's most important sources of income [79]. BAZNAS [51] estimate the potential of the whole collection of zakah in Indonesia is around Rp. 90 to Rp. 100 trillion per year.

In details, the potential for the zakah mal alone is around Rp. 20 trillion, however the amount successfully collected is only about Rp. 1.3 trillion (6 percent). There are still 94 percent of the zakah that has not been collected [80] shows that the potential for zakah has not managed well [72]. Result of [35] which compares the revenue collection of zakah in Kedah (Malaysia) with the provinces of Aceh (Indonesia) between 2006 and 2009, showed that, in the Kedah collection of zakah is greater than the collection of in Aceh. In fact, the population of Muslim in Aceh is more numerous than Kedah. Reference [19] also made a comparative study of the management of zakah in Medan (Indonesia) and Penang (Malaysia). In 2000, the amount of zakah collection in Penang is RM 148 million or Rp. 37.5 billion, while the number of zakah collection in Medan is Rp. 2.0 billion. Note the comparison of the Muslim population in Penang is 1,390,200 people and in Medan is 2,006,142 people. Why is this happening? Several and complicated factors influence this situation. Reference [72] highlighted reason why potential zakah not fully maximized which related the weakness on juridical, sociological and institutional aspects.

\subsection{Juridical Aspect}


The juridical aspect related to several problems. Although zakah laws exist, there are still many weaknesses. In the implementation of Law No. 38 years 1999 appears to potentially inhibit the development of zakah because of three reasons there are;

First. There is no clear separation between the functions of regulation, supervision, and implementation of the organizing zakah. Impact of this weakness is associated with lack of coordination and determination of zakah collection and distribution. The problem lack of coordination, both between the central and local BAZ, among the LAZ in the community, and between BAZ and LAZ has been acknowledged by [77]. The end result is a overlapping occurs in distribution of zakah in the community.

Second. Implementation of action for the muzakki sentence in default or refusal to pay zakah is questionable, though it has been categorized as compulsory. Lack of actions enforced on the muzakki to perform his/her obligations expectedly is one of the problems confronting the successful management of zakah in Indonesia. This situation has resulted in prolonged debate in Indonesia. Article 23 (A) of the Indonesian constitution said taxes and "other collections" that are forced to the needs of the country is governed by the Law. There has been no clarity that the zakah is included in "other collections" that are forced to serve national needs. Therefore, action to impose sanctions on a default muzakki is not available or done. The absence of sanctions for Muzakki who do not want to pay zakah, not pointed the board of justice to adjudicate offenses committed by management and the lack of zakah organization elements in UUPZ body are among the problems that hinder the collection of zakah to be more effective. Therefore, the increase in Law Enforcement is also deemed necessary to zakah. Muzakki clause to sanction for the default can be done through the District Rules (Trade) [81].

Third. The tax system applied in Indonesia which is considered as double tax payment by zakah and government tax payers [19]. Muslim community feel overburdened with this system of having to pay tax and zakah. In Indonesia, the payment of zakah can only reduce the "total earnings subject to tax" (taxes deductable) [53]. Proposed adoption of zakah as a component of tax reduction would require a legal basis to modify (amend) the existing zakah regulation. To accommodate this proposal, the Indonesian government has already issued a new regulation that governs religious zakah or donations, thus can be reduced from gross income or tax reduction. The Regulation No. 36 of 2008 states that zakah can be a reduction in taxable revenue. Tax is considered as a cost as zakah. This regulation followed by The Government Regulation (PP) No.60 of 2010. However, this regulation is considered not quite useful. Some authorities feel that this regulation is not adequate because it was not a significant motivating factor for Muslims to pay zakah. This policy is still considered lagging behind compared to other countries that already have policies 'tax credit' to that effect. Next on article 11 paragraph 3 of Law No. 38 of 1999 stated, "Zakah is paid to BAZ or LAZ reduced from gains / income from taxable waste taxpayer in accordance with rules related legislation is happening". Subject to the provisions about the zakah is only valid as reducing the production of taxable (BCP) until no significant impact in encouraging the development of zakah in Indonesia [82]. According to [61] tax reduction has not been a stimulus to pay zakah because zakah can be a reduction of tax payments, but its value is very small. This is also because it is only calculated from the total taxable income. This policy is considered far behind compared to other countries already having well developed policies regarding tax credit regulations.

The payment of zakah is only to reduce the amount of taxable income or tax reduction also said by [53], while zakah in this sense means reduction in the amount of income tax due (tax credit). Example of zakah calculation of "tax reduction" is if the total income of Rp. 200 million per year, then the payment of zakah $(2.5 \%)$ is Rp. 5 million. Total taxable income now is Rp. 195 million. Then the income tax to be paid is $10 \%$ x Rp. 195 million $=\mathrm{Rp} .19 .5$ million. Thus the amount to be paid is Rp. 5 million (zakah) + Rp. 19.5 million $(\operatorname{tax})=$ Rp. 24.5 million. While the calculation of "tax credit" from similar amount of total income explained below. Total zakah need to pay (2.5) is Rp. 5 million. Total taxable income tax is $10 \% \times \mathrm{Rp} .200$ million $=$ Rp. 20 million. If a person has to pay zakah amounting to Rp.5 million, the total balance due payable tax is only Rp. 15 million.

Tax reduction regulation applies in all parts of Indonesia, except in Aceh Darussalam (NAD) Province. NAD Province is a special autonomous province, according to article 192 of Regulation No.11 of 2006 on Governing Aceh. The state has its own rules of zakah as a factor reducing the amount of income tax due (tax credit). This means Muslims of NAD province obtain tax deductible. From the above examples/calculations Muslims in NAD Province get income tax relief amounting to Rp. 4.5 million from income of Rp. 200 million, (tax deductible Rp. 19.5 million, Taxes credit Rp. 15 million). These rules make people not to feel overburdened and one of the reasons of zakah payment evasion. Reference [20] found out factors must be accounted for as a tax system to determine the compliance and evasion zakah. This is when the issues are still considered burden some tax payer if the payment of Zakah is not provided for tax rebates, especially for the corporate sector. The government in this case by providing tax rebate for corporations in effect encourages the corporate sector to assist the government in reducing the sufferings of the less fortunate in the society [83]. Therefore, one of the suggested methods to increase the collection of zakah is by applying zakah as a component of a tax reducing system [70]. These factors are classified as external factors. It can also be classified as rational factors. Rational principle is 
based on physical satisfaction (worldly) only. Rationalism is defined as a process of maximizing a requirement based on a set of constraints. This kind of definition according to [84] to be interpreted the same again if you want to use the term in Islamic economics as the term is still somewhat vague because any item can be rationalized by reference to a particular set of axioms or principles. Therefore, in accordance with Islamic principles, the basis of rational satisfaction is not only physical but also spiritual satisfaction. To understand the concept of rationalism to Muslims, then the space to enjoy the satisfaction of life time should be extended to two dimensions, namely life, and life in the hereafter. Any action will affect the welfare of both the nature of life. Therefore, the assumption of rationality is based on the benefits of this world as well as on the rewards of the Hereafter [12]. Thus the behavior of individuals in selecting the results that can achieve present values of his satisfaction is through good life and the hereafter [44]. Therefore, Muslims must act rationally when they release some personal use or consumption in order to spend the economy in the interests of society and religion. It is willing to do so to increase the satisfaction of a more comprehensive satisfaction includes the satisfaction of physical (material) and spiritual satisfaction. By the philosophy that requires Muslim zakah that could help others in need is a rational action. According to [85], evidence of Muslims seek ways to maximize the utility of physical and spiritual utility had spoken by Allah in the Qur'an Surah Al-Baqarah, verse 201, But among them is he who says, "Our Lord, give us in this world [that which is] good and in the Hereafter [that which is] good and protect us from the punishment of the Fire.". Thus, to maximize utility, as well as external factors such as law enforcement with fines and penalties provision of clear and decisive, Muslim individuals has not escaped the influence of internal factors such as faith and morals (morals). Therefore if the whole community was rich and there are no eligible recipients even, regular zakah is obligatory.

\subsection{Sociological Aspect}

Based on the sociological aspect of the mustahiq, it is classified into two categories namely internal and external factors.

Internal factors related to the limitation knowledge of mustahiq about the zakah. Generally, people know more about prayer, fasting and pilgrimage but low awareness on understanding, honesty and sincerity. There are still many Muslims in Indonesia who do not know that zakah is compulsory. The rest, assume that zakah is similar to donation, which is a voluntary worship, not be forced and only based on sincerity. According to [70] this is the paradoxical part of Muslims in Indonesia, where the number of poor people is a lot and most of the muzakki do not believe that zakah is compulsory. The muzakki need to realize that zakah is compulsory and has been designated as part of the pillars of
Islam. Reference [9] said that Zakah is one of the fundamental principles of Islam and that in al-Qur'an, zakah is mentioned in the same sentence with prayer for 82 times [7]. From this statement one should be informed of the importance of zakah in Islam, which is like a synergy to prayer. Allah has given strong warnings against those who refuse to pay zakah. According to Surah At-Tawbah verse $34-35$, in the hereafter, properties stored and stacked without paying zakah will be turned into punishment for the owner. Unfortunately, there are still many Indonesian Muslims who do not understand or do not want to understand the obligation to pay zakah.

External factor, which highlighted is the low belief of muzakki to the board of amil zakah [50,62]. There are some indications that fear of community that zakah not reach mustahiq properly. This factor appears related to the weak application of the organizational management principles in organizing zakah fund.

\subsection{Institusional Aspect}

As the level of trust and the level of knowledge on zakah management from the community is low, the government's role very important and strategic to overcome these problems [76]. Furthermore it underlines some important points to optimize the potential of zakah through enlightenment, beliefs, socialization and understanding. Socialization is quite an important role in raising public awareness of the pay zakah. Increased awareness of and compliance with the Muslim community in the zakah is related to efforts socialization intensively conducted by the government, Islam organizations, and social organization, especially BAZ and LAZ [86]. Socialization can be shaped, first, public awareness will perform the duty of zakah is an important aspect to be performed by a board of zakah. Enlightenment can be persuasive manner (busyro) or good news, warning and belief.

Busyro. With this busyro we give glad tidings to the society; that people who regularly practice regular zakah, they will not perish but instead they will get good profits in the world and the hereafter. It is similar to that carried out in Malaysia, where nearly $80 \%$ of all Muslim owned businesses are not paying zakah business. Notwithstanding that the government did not intend to make laws to require that each company owned by Muslims to pay zakah. The approach taken is to persuasive [87].

Warning. It is certainly different from the situation with the early days of the reign of Rashidun al-Raasyidin. Caliph Abu Bakr al-Siddiqi for example, has decided to fight against those who default in the payment of zakah. Assertiveness can be seen from his conversation with Omar AlKhattab. He said, "By Allah, I will fight those who differentiate between prayer and the Zakah as Zakah is the right property. True action of Abu Bakr al-Siddiqi is acknowledged by Umar al-Khattab who said," By Allah, when I see God open the hearts of Abu Bakr to battle, and then I'm 
sure that is true". It is clear that the obligation to pay zakah is co-located with the duty of prayer and cannot be separated. So if someone is claiming Islam, (Shahada), then it must carry out further duty is prayer and zakah. With this warning hope the community will become aware to that people who often fail in zakah.

Beliefs. Public trust for a BAZ/LAZ is a must-have staple. Due to the beliefs of the society is a BAZ will survive. In the matter involving the management of zakah funds, Islam emphasizes the importance of the task undertaken with great trust amil. According to [88] trust is a matter closely related to the beliefs of society. Honesty is the essence of faith; trust is a trust when cashed. This approach more emotional approach (religiosity).

Professionalism is an important element to increase the level of belief (trust). In this case professionals related with performance and service. Professional according to [89] must have adequate knowledge of the accounting manager and top management support, the effective accounting (zakah) information system to increase at public trust and dramatically improved the collection and distribution of zakah. Within the meaning of words must know the intricacies of zakah, and have enough knowledge about the jurisprudence zakah. As prerequisites for zakah, zakah resources, the calculation of zakah, distribute zakah, zakah financial system and so forth. Another element can increase people's confidence is transparency that the openness of the management of zakah. This transparency must be appearing in the board, particularly on the financial and routing in a manner to publish it to the community. Socialization also play important element to increase the level of trust. Socialization should be practiced by a zakah management, because in the absence of socialization, people may not know about the existence of zakah and zakah management presence. When people have recognized the obligation to pay zakah, the zakah management board should provide an understanding to the community about the calculation and payment procedures of zakah.

The discussion above shows that the determinant of a Muslim in the payment of zakah can be categorized into two factors, namely, internal and external factors. These factors have been studied by [20] in a survey of the theory of the behavior model of compliance and avoidance of Zakah. He stated that compliance and avoidance behavior not only depends on the zakah punishment if the law enforcement but also depends on other factors, namely the commitment to religion / faith understanding / knowledge of zakah, facility payment mechanism, the belief in a formal institution of zakah, the perception of the tax system and environmental factors (the Reference or Reference group).

Reference [35] conducted a study in the administrative law zakah collection. In conclusion shows that the enforcement of the law firm followed by an organized institution with a dedicated staff and focused objectives, impact on the performance of zakah collection and public confidence in these institutions to pay zakah.

However, many suggestions given to improve the management of zakah in Indonesia, the government's role is very important. Reference [90] looked at government intervention is needed in the management of zakah because zakah is an act of stewardship of public law is the responsibility of government or board certified by the government to organize it. It is time the governments to do a real action to overcome the issue so that the potential of zakah can be used to optimum. This is in line with Islamic teachings, in a Muslim country should be collected by the national zakah or institution that is mandated by the state and on behalf of the government. In other words the government as a governor or zakah also acts as a representative of the poor. AlQur'an and al-Sunnah also shows that those who manage zakah are the government, which is an Imam or those who represent them. Allah says in At-Tawbah verse 60. Allah also says in At-Tawbah verse 103. In relation to these two sentences, Imam al-Kasani was states that an Imam has the right to claim and collect zakah. If not, then what it means mentioned "amilin" in verse Surah at-Tawbah: 60's [91]. So, ideally the government should be responsible to perform the collection and distribution of zakah and issue rules and regulations to ensure proper implementation of the zakah [38]. The government may also authorize shareholders to pay it personally if it is satisfied that they will do so, or it may instruct Islamic banks to organize its payment on behalf of Islamic banks' shareholders, using the combined basis for nisab [92].

The author is aware that it is not easy to get an ideal situation. That is why the various parties in Indonesia pushed for amendment of the Zakah regulation to take immediate effect, as it is far from ideal and there are many disadvantages that need to be corrected. To achieve that required strong political will in support of the Indonesian Muslim community. Reference [93] stated that the management of zakah can run optimally whenever there is synergy with all of the stakeholders (muzakki, the amilin and policy makers).

\section{Conclusion}

Various reforms and new ideas in the management of zakah in Indonesia is growing, starting from 1999 the management of Indonesia Zakah in a more systematic. Zakah is organized by the government (BAZ) and non government (LAZ). The role of mosque and traditional Islamic boarding schools (pesantren) would not be denied. Despite so many parties involve, the management of zakah in Indonesia is not optimal and could not dig the great potential of the country with world's largest Muslim population. Still many gaps were available that become the weakness of zakah management and requires immediate action. These weaknesses come from the community (sociological as- 
pects), government (juridical aspects), and the management of zakah (amil). Therefore, the improvement of zakah management should be done, by all stakeholders so that the potential of zakah to be optimal.

\section{Acknowledgements}

The authors acknowledge with gratitude the support given by Universiti Sains Malaysia (USM) through the USM Fellowship to the first author.

\section{References}

[1] Al-Habshi, S. O. (2003). Peranan Zakat dalam Membantu Pembangunan Ekonomi Negara. Persatuan Ekonomi dan Pengurusan Islam Malaysia.

[2] Hamizul, A. H. (2012). Ekslusif Zakat. Selangor: Galeri Ilmu Sdn.Bhd.

[3] Muhammad, A.(1980). A Note on the Concept of Zakah and Taxation, In Raquibuzaman, M. (Ed.). Some Aspects of the Economics of Zakat. Indiana: American Trust Publications.

[4] Norazlina, A.W. \& Abdul, R. A. R. (2011). A Framework to Analyse the Efficiency and Governance of Zakat Institutions. Journal of Islamic Accounting and Business Research, 2(1): pp. 43-62.

[5] Muhammad, A. A. \& Nur, B. A. B. (2009).Accounting Treatment for Corporate Zakat: A Critical Review. International Journal of Islamic and Middle Eastern Finance and Management, 2(1), pp. 32-45.

[6] Abu Bakar, N. B. (2008). Study Guide: Zakat Accounting Concepts and Applications, Kuala Lumpur: Wisewords Publishing.

[7] Sabiq, S. (1987). Fiqh Sunnah, Beirut: Dar al-Kitab, alAraby.

[8] Al-Jaziri, A. (1990). Kitab al-Fiqh 'Ala Mazahibul Arba'ah, Beirut: Dar al-Fikr, 19, Juz.I, p. 590.

[9] Metwally, M. M. (1997). Economic Consequences of Applying Islamic Principles in Muslim Societies. International Journal of Social Economics, 24(7/8/9), pp. 941 - 957.

[10] Al-Ghazali, M. (1997). Muslim's Character.International Islamic Federation of Student Organizations, Riyadh. International Islamic Publishing House.

[11] Abdalati, H. (1980). Islam in Focus. Islamic Teaching Centre, Riyadh, pp. 126-129.

[12] Toseef, A. (2010). Anthology of Islamic Economics: Review of Some Basic Issues. Review of Islamic Economics, 13(2), pp. 165-194.

[13] Mohyi, A. A. A. (2011). The Obligation of Zakóh Upon A Legal Entity. ISRA International Journal of Islamic Finance, 3(1), pp.169-174.

[14] Hairunnizam, W., Sanep, A. \& Radiah, A. K. (2009). Pengagihan Zakat oleh Institusi Zakat di Malaysia: Mengapakah Masyarakat Islam Tidak Berpuashati? Jurnal Syariah. 17(1), pp. 89-112.

[15] Al-Krenawi, A. \& Graham, J. R. (2000). Islamic Theology and Prayer: Relevance for Social Work Practice.International Social Work. 43(3), pp. 289-304.

[16] Azmi, S. H. (1991). Traditional Islamic Social Welfare: Its Meaning, History and Contemporary Relevance, Part IIII." Islamic Quarterly XXXV, no-3,4 \& XXXVI, no. 1.

[17] El-Azayem, G. A. \& Diba, Z. H. (1994). The Psychological Aspects of Islam: Basic Principles of Islam and Their Psychological Corollary. International Journal for the Psychology of Religion, 4(1), pp. 41-50.

[18] Qardhawi, Y. (2002). Kiat Islam Mengentaskan Kemiskinan. Jakarta: Gema Insani Pers.

[19] Maratua, S. (2006). Pengelolaan Zakat di Medan dan Pulau Pinang: Satu Kajian Perbandingan. Tesis Doktor Falsafah, Universiti Sains Malaysia.

[20] Sanep, A. \& Zulkifli. (2010). Model Gelagat Pematuhan dan Pengelakan Zakat: Suatu Tinjauan Teori.Presented at 7th International Conference - The Tawhidi Epistemology: Zakat and Waqa fEconomy, Bangi, Malaysia.

[21] Muhammad, Z. A. B. (2011). Prinsip-prinsip Tadbir Urus dalam Transformasi Institusi Zakat. In Muhammad S. S., Mohammmad S. A, B., Zahri, H. (Eds.). Transformasi Zakat.Pusat Urusan Zakat (PUZ) Pulau Pinang dan Pusat Kajian Pengurusan Pembangunan Islam (ISDEV). Pulau Pinang, Malaysia.

[22] Qardhawi, Y. (2004). Hukum Zakat. Litera Antar Nusa, Jakarta.

[23] Monzer, K. (1995). Applied Institutional Models for Zakah Collection and Distribution in Islamic Countries and Communities. In El-Asker, A. A. F. \& Haq, M. S. (Eds.). Institutional Framework of Zakah: Dimentions and Implications, Jeddah: IRTI/IDB, pp.197-228.

[24] Monzer,K. (1997). Potential Effects of Zakat on Government Budget. Journal of Economics and Management 5, pp. 67-85.

[25] Choudhury,M. A. \& Harahap, S. S. (2008).Interrelationship Between Zakat, Islamic Bank and the Economy: A Theoretical Exploration.Managerial Finance.34(9),pp.610-617.

[26] Permono, S. H. (1997). Sumber-sumber Penggalian Zakat, Pustaka Firdaus. Jakarta.

[27] Fuadah, J. (2004). Keberkesanan Zakat Dalam Mengatasi Maslah Kemiskinan di Negeri Malaka. Disertasi Master Jabatan Syariah dan Ekonomi, Bahagian Pengajian Syariah, Akademi Pengajian Islam, Universiti Malaya.

[28] Dimas, B. W. K.\& Raditya, S. (2010). The Power of Zakah in Poverty Alleviation. Seventh International Conference The Tawhidi Epistemology: Zakat and Waqf Economy, Bangi, Malaysia.

[29] Kabir, H. M. (2010). An Integrated Poverty Alleviation Model: Combining Zakat, Awqaf and Micro-finance. Seventh International Conference - The Tawhidi Epistemology: Zakat and Waqf Economy, Bangi 2010. http://www.ukm.edu.my/hadhari/sites/default/files/prosiding 
/p14.pdf. Accessed 14 June 2012.

[30] Abdus, S. \& Glenn, L. M.(2010). Development of Zakah and Zakah Coverage in Monotheistic Faiths.International Journal of Social Economics. 37(4), pp. 302-315.

[31] Nur, B. A. B. \& Abdul,R. A. R. (2007). A Comparative Study of Zakah and Modern Taxation. J. KAU: Islamic Economic. 20(1), pp. 25-40.

[32] Samad, A., Gardner, N. D. \& Cook, B. J. (2005). Islamic Banking and Finance in Theory and Practice: The Experience of Malaysia and Bahrain. The American Journal of Islamic Social Sciences. 22(2), pp. 69-86.

[33] Patmawati, I. (2011). Mengoptimalkan Pembiayaan Dana Zakat Untuk Golongan Miskin dan Memerlukan.In Muhammad S. S., Mohammmad S. A. B., Zahri, H. (Eds.).Transformasi Zakat.Pusat Urusan Zakat (PUZ) Pulau Pinang dan Pusat Kajian Pengurusan Pembangunan Islam (ISDEV). Pulau Pinang, Malaysia.

[34] Sudewo, E. (2010). Kualitas LAZ Ditingkatkan. www.republika.co.id.Accessed 1 May 2010.

[35] Jasni, S. \& Anwar, M. A. (2012). Kajian Perbandingan Dalam Pentadbiran Undang-Undang Kutipan Zakat di Provinsi Aceh dan Negeri Kedah. Kajian Malaysia, 30(1), pp. $107-138$.

[36] Muhammad, Y. H. A. (1995).Yemen (A Case Study of Zakah Management).In. El-Asker, A. A. F. \& Haq, M. S. (Eds.) Institutional Framework of Zakah: Dimensions and Implications. Jeddah: IRTI/IDB, pp. 439-469.

[37] Faiz, M. (1995).Relationship between Obligatory Official Zakah Collection and Voluntary Zakah Collection by Charitable Organizations.In El-Asker, A. A. F. \& Haq, M. S. (Eds.). Institutional Framework of Zakah: Dimensions and Implications, Jeddah: IRTI/IDB. Pp, 163-195.

[38] Monzer, K. (2000).Zakah Management in Some Muslim Societies. 2 ed. Jeddah: IRTI/IDB.

[39] Shamsiah, A. K. (2006).Penerapan Budaya Moden dalam Pengurusan dan Administrasi Zakat di Singapura.Persidangan Zakat Asia Tenggara. Kuala Lumpur.

[40] Mahani, M. \& Abdul, W. S. (2008).Zakat Development in Brunei Darussalam.In International Zakat Executive Departement Programme Seminar.Islamic Trainning Institute of Malaysia (ILIM), Selangor, Malaysia.

[41] Mohd, I. S. \& Iwansuzairie, H. (2008) Zakat: Collection and Distribution in Malaysia.In International Zakat Executive Departement Programme Seminar.Islamic Trainning Institute of Malaysia (ILIM), Selangor, Malaysia.

[42] Nasser, A. A. (2008).Zakat in Saudi Arabia.In International Zakat Executive Development Programme Seminar.Islamic Training Institute of Malaysia (ILIM), Selangor, Malaysia.

[43] Fuad, A. A. O. (2000).Management of Zakah through SemiGoverment Institution. In.Imtiazi , I. A., Mannan, M. A., Niaz, M. A. \& Devia, A. H. (Eds.).Management of Zakah in Modern Muslim Society. Jeddah: IRTI/IDB, 131-151.

[44] Monzer, K. (1995). Ekonomi Islam, Telaah Analitik terhadap Fungsi Sistem Ekonomi Islam (Indonesian translation version of The Islamic Economy: Analytical of the Func- tioning of the Islamic Economic System). Yogyakarta: Pustaka Pelajar.

[45] Monzer, K. (1999). The Performance of the Institution of Zakah in Theory and Practice. Paper presented in The International Conference on Islamic Economics Toward The 21 st Century, Kuala Lumpur 26-30 April,1999.

[46] Aflatun, M. (2005). Anatomi Fiqh Zakat. Pustaka Pelajar: Yogyakarta.

[47] Ahmad, J. (2009).Tinjauan Kritis Penghapusan LAZ oleh Pemerin-

tah.http://asosiasizakat.blogspot.com/2009/12/.Accessed 12 June 2012.

[48] Mohamed,A. H.(2012) Southeast Asia, Islam and Economy in.Oxford Islamic Studies Online.

[49] BPS.(2010).Laporan Tahunan Jumlah Penduduk di Indonesia

http://bps.go.id/Tabel/penduduk/JumlahPenduduk.html.Acc essed 10 June 1012.

[50] PIRAC.(2008).Meningkat Kesadaran dan Kapasitas Masyarakat dalam Berzakat. http://www.pirac.org/teliti_ZA.htm.Accessed 5 June 2012.

[51] BAZNAS(2008).Laporan Keuangan. www.baznas.or.id. Accessed 25 April 2012.

[52] Amrullah.(2010).Zakat dalam Perspektif UU Pemerintahan Aceh.www.baitulmal-aceh.com. Accessed 4 April 2010.

[53] Amrullah.(2010).Adakah Transparansi dalam Pengelolaan Zakat Di Aceh. www.baitulmal-aceh.com.Accesed 11 November 2010.

[54] Baitul Mal. (2009).Laporan keuangan www.baitulmalaceh.com. Accesed 5 November 2009.

[55] Fadzila, A. A. (2010).Kaedah Pengurusan Institusi-Institusi Pembangunan Berteraskan Islam di Malaysia. Shah Alam: Pusat Penerbitan Universiti (UPENA).

[56] Sidi, G. (1976). Masyarakat Islam. Cetakan I. Kuala Lumpur: Pustaka Antara.

[57] Muhammad, S. S., Haron, A. Shahidan, S \& Wan Asna, W. H. N. (2002).Kajian Menjadikan Masjid Putra di Putrajaya Sebagai Masjid Model Negara. Unit Pemodenan Tadbiran dan Perancangan Pengurusan Malaysia (MAMPU), Jabatan Perdana Menteri Malaysia. Malaysia.

[58] Hairunnizam, W., Sanep, A. \& Radiah, A. K. (2010). Pengagihan Zakat oleh Institusi Zakat kepada Lapan Asnaf: Kajian di Malaysia. Jurnal Pengurusan JAWHAR. 4(1), pp. 141-170.

[59] Zayas, F. G. (2003).The Law and Institution of Zakat. Kuala Lumpur: The Other Press.

[60] Muhammad, S. S. (2006). Lokalisasi Pengagihan Zakat: satu Cadangan Teoritis.In Hailani \& Abdul G (Eds.). Zakat: Pensyariatan, Perekonomian \& Perundangan. Bangi: Universiti Kebangsaan Malaysia Press.ISBN 967-942-795-1.

[61] Hafidhuddin, D. \& Juwani, A. (2010). Zakat Atasi Kemiskinan.www.republika.co.id. Accessed 31 Mac 2010. 
[62] Marlina, E. (2010). Memperkasakan Pengurusan Zakat di Institusi: Isu dan Cabaran. Kertas dibentangkan dalam Persidangan Antarabangsa Pengurusan Pembangunan Islam (IDMAC) ke-4 Anjuran Pusat Kajian Pengurusan Pembangunan Islam (ISDEV) Universiti Sains Malaysia (USM) pada 21 dan 22 Disember 2010, Pulau Pinang, Malaysia.

[63] Subianto, A. (2010).Gerakan Memakmurkan Masjid.www.memakmurkanmasjid.com. Accessed 5 May 2012.

[64] Taufik, A. (1991).Zakat Collection and Distribution in Indonesia.In Mohamed A (Ed.). Islam and The Economic Development of Southeast Asia: The Islamic Voluntary Sector in Southeast Asia, Singapore: Institute of Southeast Studies, pp. 50-84.

[65] Mujamil, Q. (2005). Pesantren: dari Transformasi Metodologi Menuju Demokratisasi Institusi. Jakarta: Penerbit Erlangga.

[66] Nawawi.(2006).Sejarah dan Perkembangan Pesantren.Jurnal Studi Islam dan Budaya. 4(1), pp. 4-19.

[67] Mastuhu(1989).Dinamika Pendidikan Pesantren.Disertasi Pasca Sarjana Institut Pertanian Bogor. Indonesia.

[68] Dhofier, Z. (1990). Tradisi Pesantren, Studi Tentang Pandangan Hidup Kiai Jakarta: LP3ES. Indonesia.

[69] Fauzia, A. (2009). Polemik Pengelolaan Zakat. www.csrc.or.id.Accessed 18 May 2009.

[70] Susetyo, H. (2009). Peran Negara dalam Pengelolaan Zakat: Perspektif Negara-Negara Kesejahteraan dan Praktek Negara-Negara Tetangga.www.imz.or.id. Accessed 24 Julai 2009.

[71] Kurniawati. (2005). Muslim Philanthropy: Potential and Reality of Zakat in Indonesia, Survey Results in Ten Cities. Kota Depok: Piramedia. Indonesia.

[72] Ahmad, W. H. (2010).Peran Negara Dalam Mengoptimalkan Zakat di Indonesia, Jurisdictie, Jurnal Hukum dan Syariah. 1(2), pp. 1-92.

[73] Mohamed, D. A. L. (1998). Zakat Management and Administration in Malaysia. Paper presented on Seminar of Zakat and Taxation at Universiti Islam Antarabangsa Malaysia. Kuala Lumpur.

[74] Sanep, A., Hairunnizam,W. \& Adnan, M. (2006). Penswastaan Institusi Zakat dan Kesannya Terhadap Pembayaran Secara Formal di Malaysia.International Journal of Management Studies. 13(2), pp. 175-196.

[75] Aidit, G. (1989). Fenomenon Pembayaran Zakat Melalui Saluran Tidak Rasmi: Satu Analisis Empirik. In. Baharum, M. A. (Ed.) Zakat Ditinjau dari Perspektif Sosial, UndangUndang dan Taksiran. Kuala Lumpur: Dunia Press Sdn. Bhd.

[76] Mahmud, H. (2012). Peranan Negara dalam Pengelolaan Zakat dalam Menghadapi Pasar Tunggal ASEAN 2015. Fakultas Agama Islam Program Studi Ahwal As-Syakhsiyah Universitas Pesantren Tinggi Darul Ulum Jombang. Indonesia.

[77] Muhammad, A. T. (2010). Problematika Pengelolaan Zakat. http://www.forumzakat.net.Accessed 12 June 2012.

[78] Ahmad, J., Mochammad, S., Mohammad, B. A. \& Tri, E.
(2008).Zakat Management in Indonesia.International Zakat Executive Departement Programme Seminar.Islamic Trainning Institute of Malaysia (ILIM) Selangor. Malaysia.

[79] Zahri, H. (2007). Perakauanan Zakat Perniagaan di Malaysia: Satu Kajian Rintis Pendapat Cendekiawan Zakat. Thesis Doktor Falsafah, Pusat Pengajian Sains Kemasyarakatan, Universiti Sains Malaysia.

[80] Bramasetya, S. A. (2010). Revisi UU Zakat 2010 Jangan Hapus Peran BAZ.www.republika.co.id. Accessed 5 September 2010.

[81] Ahmad, J. (2009). Membangunkan Kekuatan Zakat Indonesia. http://www.imz.or.id. Accesed 24 June 2012.

[82] Ria, C. A. (2012). Peran Negara dalam Merevitalisasi Pengelolaan Zakat Sebagai Upaya Strategis MenanggulanganKemiskinan Di Indonesia, Fakultas Hukum Universitas Brawijaya Malang. Idonesia.

[83] Abdul, R. A. R. (2007).Pre-requisites for Effective Integration of Zakah into Mainstream Islamic Financial System in Malaysia. Islamic Economic Studies, 14, pp. 1 - 2.

[84] Monzer, K. (1982). Taxation Policy in an Islamic Economy. In Ziauddin Ahmad (Ed.).Fiscal Policy and Resource Allocation in Islam.Jeddah ; International Centre for Research in Islamic Economics.King Abdul Aziz University.

[85] Mahmud, Y.(1973). Tafsir Qur'an Karim. PT.Hidakarya Agung. Jakarta.

[86] PIRAC. (2007). Press Release: Meningkat, Kesadaran dan Kapasitas Masyarakat dalam Berzakat. http://pirac.org. Accessed 5 June 2012.

[87] Helmi, M. F. (2002). Hampir 80\% Syarikat Islam Tidak Bayar Zakat.www.utusan.com.my. Accessed 24 June 2012.

[88] Mohd, T. A. W. (2008). Tanggungjawab Amil dalam Pengurusan Zakat Negeri Selangor. Paper presented in Seminar Pemantapan Integriti dan Akauntibiliti Dalam Pengurusan Zakat Negeri Selangor, 27 Ogos 2008, Majlis Agama Islam Selangor (MAIS)Malaysia.

[89] Adeh, R. K. (2012). The influence of the Accounting Manager Knowledge and the Top Management Support to the Accounting Information System and it's Impact on the Quality of Accounting Information: Survey in Management Institution of Zakat in Bandung. Proceeding of 3rd International Conference On Business And Economic Research (3rd ICBER 2012), 12 - 13 March 2012, Bandung, Indonesia.

[90] Budi, P. (2008). Optimalisasi Pengelolaan Zakat pada Badan Amil Zakat Daerah (Tinjauan Terhadap Badan Amil Zakat Daerah Kabupaten Muna Propinsi Sulawesi Tenggara). Fakultas Hukum Universitas Diponegoro Semarang. Indonesia.

[91] Permono, S. H. (1995). Pemerintah Republik Indonesia Sebagai Pengelola Zakat, Pustaka Firdaus, Jakarta.

[92] AAOIFI.(2001).Accounting, Auditing and Governance Standards for Islamic Financial Institutions.www.aaoifi.com. Accessed 10 June 2012.

[93] Dompet Dhuafa (2011).www.dompetdhuafa.org.Accessed 

Management and Obstacles

15 June 2012. 